\title{
PERENCANAAN SISTEM PEMBANGKIT LISTRIK DENGAN SUMBER ENERGI TERBARUKAN (HOMER) DI DAERAH PESISIR PANTAI PANGANDARAN
}

\author{
Abil Wali Akbar ${ }^{1}$, Nurul Hiron ${ }^{2}$, Nidar Nadrotan ${ }^{3}$ \\ (Teknik Elektro, Fakultas Teknik, Universitas Siliwangi, Tasikmalaya, Indonesia) ${ }^{123}$ \\ Email : abilwaliakbar@gmail.com ${ }^{I}$
}

\begin{abstract}
Pangandaran Subdistrict is an area located in the lowlands near the coast, located in the southernmost area of Pangandaran, North: Ciamis Regency, West: Tasikmalaya Regency, South: Indian Ocean, East: Cilacap Regency which is $7^{\circ} 41^{\prime} 56.4$ "S (South Latitude ) $108^{\circ} 39^{\prime} 25.2^{\prime \prime} E$ (East Longitude) and is a major tourist area in Pangandaran Regency. It consists of eight villages with an area of 344,072 hectares with a population density of 20,417 familys. The Pangandaran region has the potential for renewable energy namely solar energy, wind energy and sea wave energy based on data obtained from the National Aeronautics and Space Administration (NASA) and the Meteorology, Climatology and Geophysics (BMKG) with an average solar radiation of $4.6 \mathrm{kWh} / \mathrm{m} 2 /$ day, wind speed of $4.42 \mathrm{~m} / \mathrm{s}$ and sea wave speed of $30.49 \mathrm{~m} / \mathrm{s}$, then with the help of the HOMER Energy software, hybrid-based power generation system planning can be. Homer is software used to design an energy system. plan can be plan Homer works based on 3 things, namely simulation, optimization, and synergy analysis, it can be seen the most effective, efficient and optimal combination of power systems.
\end{abstract}

Keywords: Hybrid Energy, Hybrid Power Plants, OWC, Photovoltaic, Wind Turbine

\begin{abstract}
Abstrak
Kecamatan Pangandaran merupakan kawasan yang berada pada dataran rendah yang dekat dengan pantai terletak daerah paling selatan Pangandaran, Utara : Kabupaten Ciamis, Barat : Kabupaten Tasikmalaya, Selatan : Samudera Hindia, Timur : Kabupaten Cilacap tepatnya yaitu $7^{\circ} 41^{\prime} 56.4^{\prime \prime} S$ (Lintang Selatan) 108 39'25.2"E (Bujur Timur) dan merupakan daerah wisata utama di Kabupaten Pangandaran. Terdiri dari delapan desa dengan luas wilayahnya sebesar 344,072 hektar dengan kepadatan penduduk mencapai 20.417 kepala keluarga. Wilayah Pangandaran memiliki potensi energi baru terbarukan yaitu energi matahari, energi angin dan energi gelombang laut berdasarkan data yang didapat dari National Aeronautics and Space Administration (NASA) dan Badan Meteorologi, Klimatologi dan Geofisika (BMKG) dengan rata-rata radiasi matahari 4,6 kWh/m²/hari, kecepatan hembusan angin 4,42 $\mathrm{m} / \mathrm{s}$ dan kecepatan gelombang laut 30,49 m/s, maka dengan bantuan software HOMER Energy dapat dilakukan perencanaan sistem pembangkit listrik berbasis hybrid. Homer adalah perangkat lunak yang digunakan untuk mendesain sebuah sistem energi. Homer bekerja berdasarkan 3 hal, yaitu simulasi, optimasi, dan analisa sinsitifitas, dapat diketahui kombinasi power sistem yang paling efektif, efisien dan optimal.
\end{abstract}

Kata kunci: Hybrid Energy, OWC, Pembangkit Listrik Hibrid, Photovoltaic, Turbin Angin

\section{PENDAHULUAN}

Pangandaran adalah sebuah kecamatan di Kabupaten Pangandaran, Provinsi Jawa Barat Indonesia. Kecamatan ini terletak daerah paling selatan Pangandaran, Utara : Kabupaten Ciamis, Barat : Kabupaten Tasikmalaya, Selatan : Samudera Hindia, Timur : Kabupaten Cilacap tepatnya yaitu $7^{\circ} 41^{\prime} 56.4^{\prime \prime} \mathrm{S}$ (Lintang Selatan) 108 $39^{\prime} 25.2^{\prime \prime E}$ (Bujur Timur) dan merupakan daerah wisata utama di Kabupaten Pangandaran. Kecamatan Pangandaran terdiri dari delapan desa atau kelurahan yaitu Babakan, Pagergunung, Pananjung, Pangandaran, Purbahayu, Sidomulyo, Sukaurip, dan Wonoharjo yang luas wilayahnya sebesar 344,072 Ha dengan kepadatan penduduk mencapai 20.417 kepala keluarga pada desember 2018. [1]

\section{PENGERTIAN ENERGI}

Energi adalah kemampuan melakukan kerja. Kebutuhan energi di Indonesia khususnya dan di dunia pada umumnya terus meningkat karena pertambahan penduduk, pertumbuhan ekonomi dan pola konsumsi energi itu sendiri yang senantiasa meningkat. [2]
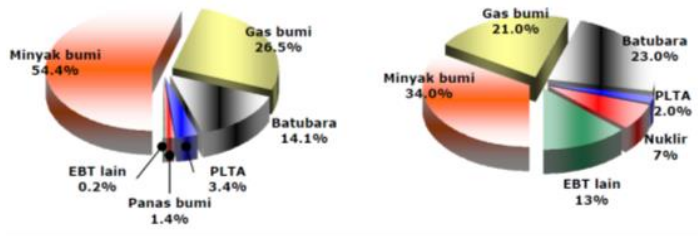

Gbr 1. Energi Mix di Indonesia dan di Dunia 2005-2025.[2]

Sistem Pembangkit Listrik Tenaga Hybrid

Pembangkit listrik tenaga hybrid merupakan integrasi dari dua atau lebih pembangkit listrik dengan sumber energi yang berbeda [3]

Dalam penelitian ini integrasi pembangkit listrik yang dipilih adalah pembangkit listrik konvensional yang besumber dari Pembangkit Listrik Negara (PLN) dengan pembangkit listrik berbasis energi baru terbarukan (renewable). 


\section{Hybrid Inverter System}

Pemakaian hybrid inverter system ini berguna agar kelebihan daya dari sistem pembangkit dapat dialirkan kembali pada jaringan PLN. Sehingga daya yang berlebih dapat dijual sesuai kesepakatan bersama. Terdapat dua jenis sistem pada Hybrid inverter sistem yaitu on grid dan of grid. [4]

\section{HOMER (Hybrid Optimization Model for Energy Renewables)}

HOMER adalah software model simulasi yang mensimulasikan sistem yang layak untuk semua kemungkinan kombinasi peralatan yang dipertimbangkan pertimbangkan.

Homer bekerja berdasarkan 3 hal, yaitu simulasi, optimasi, dan analisa sensitifitas. Ketiga hal tersebut bekerja secara beruntun dan memiliki fungsi masingmasing, sehingga didapat hasil yang optimal.

\section{Net Present Cost (NPC)}

Net presen cost (NPC) adalah semua biaya yang digunakan dalam proyek pembangunan komponen baik pemasangan maupun dalam pengoprasian suatu proyek

$$
\begin{aligned}
\mathrm{NPC}= & \text { Capital Cost }+ \text { Replacement Cost }+ \text { O\&M Cost } \\
& - \text { Salvage }
\end{aligned}
$$

Dimana :

$\begin{array}{lll}\text { Capital Cost } & \text { =biaya komponen } & \\ \text { Replacement Cost } & \text { =biaya ganti komponen } \\ \text { O\&M Cost } & \text { =biaya oprasional dan } \\ & \text { perawatan } & \\ \text { Salvage } & =\text { biaya yang tersisa dari } \\ & \text { komponen } & \end{array}$

\section{Cost of Energy (COE)}

Cost of energy merupakan biaya yang dikeluarkan untuk menghasilkan energi listrik per $1 \mathrm{kWh}$. COE dapat diketahui dengan membagi biaya tahunan dengan produksi energi tahunan oleh pembangkit hibrid. Nilai COE dapat diketahui dengan persamaan

$\mathrm{COE}=\frac{T A C}{\text { Eetotsarved }}$

Dimana :

TAC $($ total annulized cost $)$ =biaya total tahunan pembangkit hibrid

Etot served

$=$ total energi tahunan untuk beban $(\mathrm{kWh})$

\section{PERANCANGAN SISTEM PLTH}

A. Flowchart Penelitian

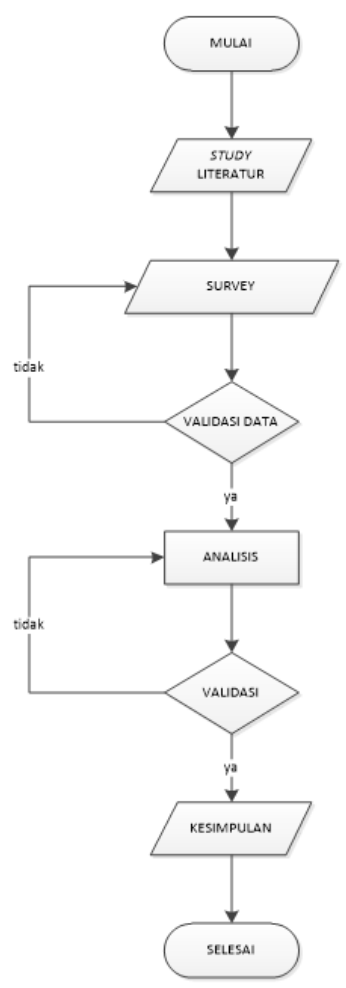

Gbr 2. Flowchart penelitian

B. Diagram Metodologi Penelitian

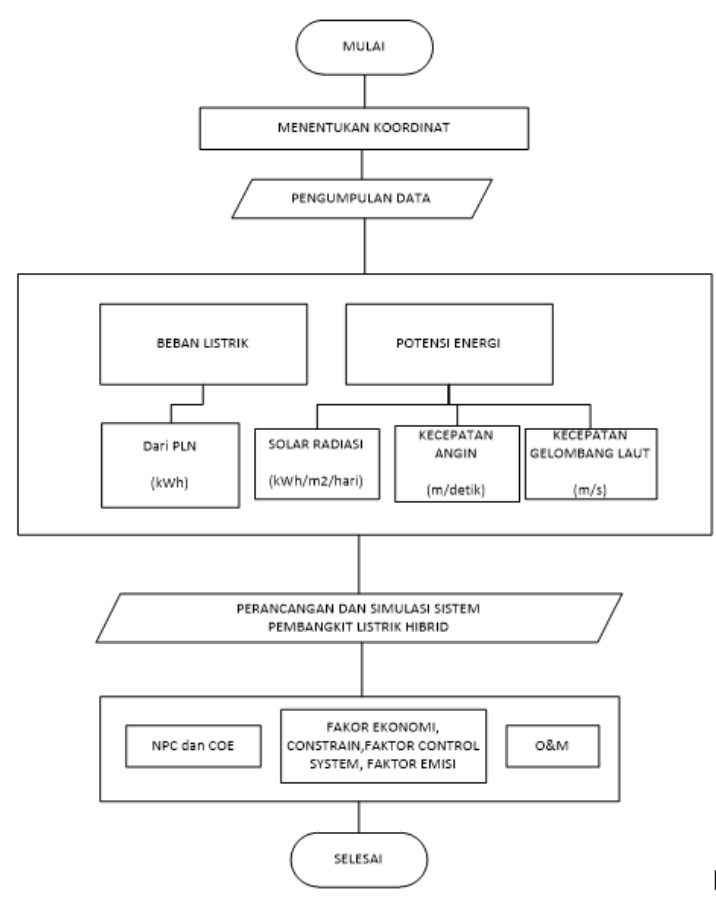

Gbr 3. Diagram Metodologi Penelitian 


\section{Blok Sistem Tenaga Hybrid On Grid}

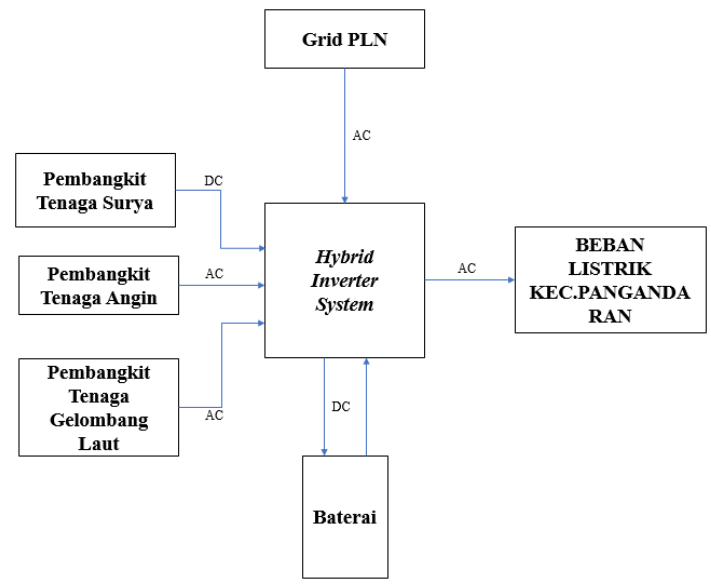

Gbr 4. Blok sistem tenaga hybrid on grid

Skema pada rancangan perencanaan PLTH tersusun dari komponen-komponen utama dari sistem perencanaan untuk pembangkit listrik di Kecamatan Pangandaran adalah Wind Turbine, Wave Turbine dan Photovoltaic, sedangkan komponen pendukungnya yaitu konverter, baterai bank dan AC DC Bus.

\section{KOMPONEN TENAGA HYBRID}

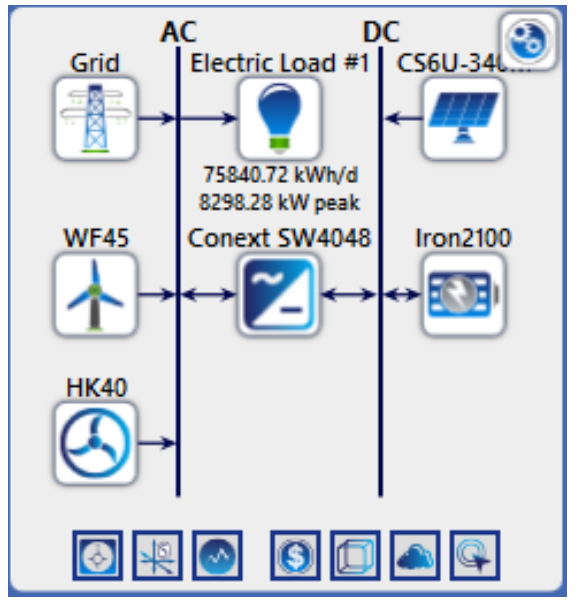

Gbr 5. Konfigurasi Sistem Pembangkit Listrik Hybrid pada HOMER

$\mathrm{Tbl}$ 1. Biaya pengganti, lifetime dan oprasi pemeliharaan komponen

\begin{tabular}{|c|c|c|c|}
\hline $\begin{array}{l}\text { Satuan } \\
\text { Kompon } \\
\text { en }\end{array}$ & $\begin{array}{c}\text { Biaya } \\
\text { Pengganti }\end{array}$ & Lifetime & $\begin{array}{c}\text { Operasi } \\
\text { dan } \\
\text { Pemelihar } \\
\text { aan }\end{array}$ \\
\hline $\begin{array}{l}\text { Turbin } \\
\text { Angin }\end{array}$ & $\begin{array}{l}\text { Rp. } \\
6.960 .134 .403 \\
, 65\end{array}$ & 20 tahun & $\begin{array}{l}\text { Rp. } \\
100.000 .00 \\
0,00\end{array}$ \\
\hline $\begin{array}{l}\text { Panel } \\
\text { Surya }\end{array}$ & $\begin{array}{l}\text { Rp. } \\
3.890 .606,02\end{array}$ & 25 tahun & $\begin{array}{l}\text { Rp. } \\
100.000,00\end{array}$ \\
\hline $\begin{array}{l}\text { Turbin } \\
\text { Gelomba } \\
\text { ng Laut }\end{array}$ & $\begin{array}{l}\text { Rp. } \\
194.878 .911,7 \\
9\end{array}$ & 10 tahun & $\begin{array}{l}\text { Rp. } \\
1.000 .000,0 \\
0\end{array}$ \\
\hline Inverter & $\begin{array}{l}\text { Rp. } \\
22.202 .776,71\end{array}$ & 10 tahun & $\begin{array}{l}\text { Rp. } \\
500.000,00\end{array}$ \\
\hline
\end{tabular}

\begin{tabular}{llcl}
\hline Baterai & Rp. & 343.224 & Rp. \\
& 673.720 .577 & $\mathrm{kWh}$ & $\begin{array}{l}1.000 .000,0 \\
\end{array}$ \\
& & & 0 \\
\hline
\end{tabular}

Profil Beban Listrik

Data beban listrik Kecamatan Pangandaran dari PLN Pangandaran mencapai penjualan hingga 75.840,72 $\mathrm{kWh} / \mathrm{hari}$ dan menghasilkan pola beban listrik seperti pada gambar di bawah ini :

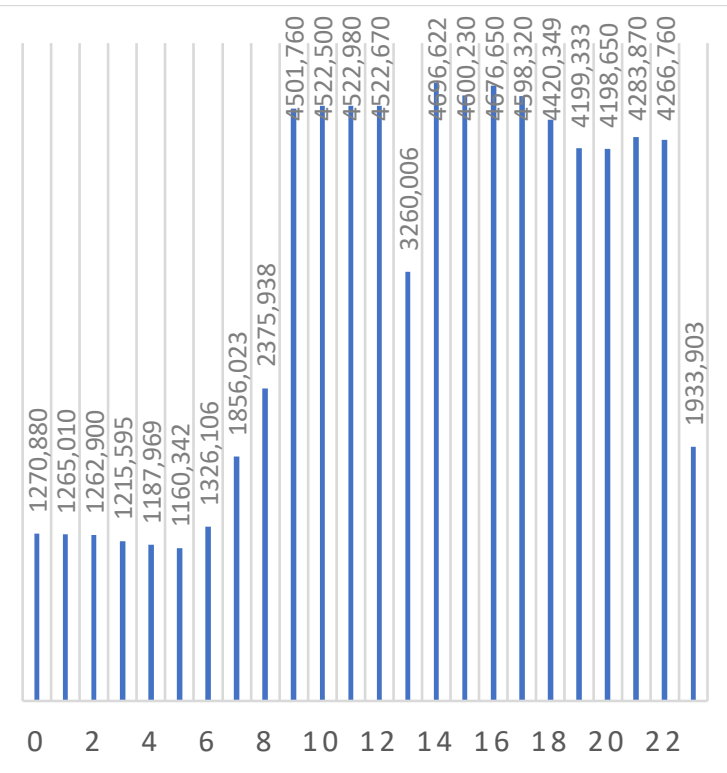

Gbr 6. Beban Listrik per jam selama 1 hari

Beban Listrik Kecamatan Pangandaran per jam selama satu hari mencapai beban puncak hingga 4676,6 $\mathrm{kW}$ dan beban minimal 1160,3 kW.

\section{A. Sumber Daya Energi Matahari}

Data radiasi didapatkan melalui "Get Data Via Internet" dimana Homer akan secara otomatis mengakses situs resmi Badan Antariksa Amerika Serikat (NASA Surface Meteorologi), kemudian akan didapatkan rata-rata radiasi matahari pertahun sekitar $4,6 \mathrm{kWh} / \mathrm{m}^{2} / \mathrm{d}$. Tabel 4.3 menunjukan nilai radiasi matahari di lingkungan pesisir pantai Pangandaran dan sekitarnya, berdasarkan pengamatan NASA.

Tb1 2. Rata-rata radiasi matahari per bulan selama 1 tahun

\begin{tabular}{cc}
\hline Mounth & Daily radiation $\left(\mathbf{k W h} / \mathbf{m}^{\mathbf{2}} / \mathbf{d}\right)$ \\
\hline January & 4,370 \\
\hline February & 4,500 \\
\hline Mart & 4,640 \\
\hline March & 4,600 \\
\hline April & 4,540 \\
\hline May & 4,350 \\
\hline June & 4,450 \\
\hline July & 4,740 \\
\hline August & 5,030 \\
\hline September & 4,840 \\
\hline October & 4,490
\end{tabular}




\begin{tabular}{cc}
\hline November & 4,600 \\
\hline December & 4,370 \\
\hline Average/year & 4,6
\end{tabular}

Puncak radiasi tertinggi matahari di Kecamatan Pangandaran ada pada bulan agustus mencapai hingga $5,05 \mathrm{kWh} / \mathrm{m}^{2} / \mathrm{d}$ dan radiasi terkecil pada bulan mei yaitu $4,350 \mathrm{kWh} / \mathrm{m}^{2} / \mathrm{d}$. Rata-rata radiasi matahari dalam satu tahun sebesar $4,6 \mathrm{kWh} / \mathrm{m}^{2} / \mathrm{d}$.

\section{B. Sumber Daya Energi Angin}

Data kecepatan angin didapatkan melalui akses situs resmi Badan Antariksa Amerika Serikat (NASA Surface Meteorologi). Didapatkan rata-rata kecepatan angin selama 1 tahun sebesar $4,42 \mathrm{~m} / \mathrm{s}$.

Tbl 3. Rata-rata kecepatan angin per bulan selama 1 tahun

\begin{tabular}{cc}
\hline Mounth & Average $(\mathrm{m} / \mathrm{s})$ \\
\hline January & 3,820 \\
\hline February & 3,940 \\
\hline Mart & 3,140 \\
\hline March & 3,540 \\
\hline April & 4,670 \\
\hline May & 5,170 \\
\hline June & 5,960 \\
\hline July & 6,040 \\
\hline August & 5,580 \\
\hline September & 4,390 \\
\hline October & 3,690 \\
\hline November & 3,040 \\
\hline December & 3,820 \\
\hline Average/year &
\end{tabular}

Puncak radiasi tertinggi matahari di Kecamatan Pangandaran ada pada bulan agustus mencapai hingga $5,05 \mathrm{kWh} / \mathrm{m}^{2} / \mathrm{d}$ dan radiasi terkecil pada bulan mei yaitu $4,350 \mathrm{kWh} / \mathrm{m}^{2} / \mathrm{d}$. Rata-rata radiasi matahari dalam satu tahun sebesar $4,6 \mathrm{kWh} / \mathrm{m}^{2} / \mathrm{d}$.

\section{Sumber Daya Energi Gelombang Laut}

Data kecepatan gelombang air laut didiapatkan melalui internet dengan mengakses situs BMKG (Badan Meteorologi, Klimatologi dan Geofisika) didapatkan rata-rata kecepatan gelombang $30,5 \mathrm{~m} / \mathrm{dt}$.

Tbl 4. Rata-rata kecepatan gelombang laut per bulan selama 1 tahun

\begin{tabular}{|c|c|}
\hline $\begin{array}{l}\text { Bulan } \\
/ 2018\end{array}$ & $\begin{array}{c}\text { [v]Kecepatan Gelombang } \\
(\mathbf{m} / \mathbf{d t})\end{array}$ \\
\hline Januari & 25.70119522 \\
\hline Februari & 31.43648208 \\
\hline Maret & 25.70119522 \\
\hline April & 28.72192513 \\
\hline Mei & 31.43648208 \\
\hline
\end{tabular}

\begin{tabular}{cl}
\hline Juni & 28.72192513 \\
\hline Juli & 36.35070423 \\
\hline Agustus & 40.60151324 \\
\hline September & 31.43648208 \\
\hline Oktober & 28.72192513 \\
\hline November & 25.70119522 \\
\hline Desember & 31.43648208 \\
\hline Rata-rata & 30,49729224 \\
\hline
\end{tabular}

Tabel rata-rata kecepatan gelombang laut per bulan selama 1 tahun menunjukan kecepatan gelombang tertinggi ada pada bulan agustus mencapai hingga 40,6 $\mathrm{m} / \mathrm{dt}$ dan kecepatan gelombang terendah ada pada bulan januari, maret dan november dengan nilai kecepatan $25,7 \mathrm{~m} / \mathrm{dt}$.

Hasil Optimasi

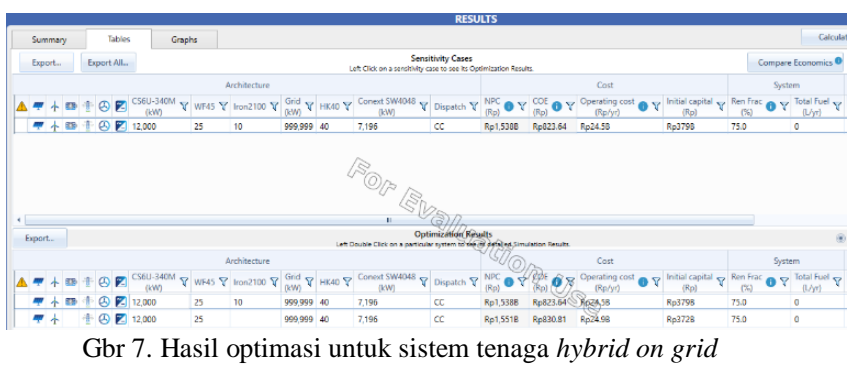

Konfigurasi sistem terhubung dengan jaringan PLN dan komponen energi terbarukan berupa $0,34 \mathrm{~kW}$ panel surya, $500 \mathrm{~kW}$ turbin angin, $48 \mathrm{~V}$ battery bank, $40 \mathrm{~kW}$ turbin gelombang laut dan konverter. Berdasarkan total Net Present Cost (NPC) terendah yaitu sebesar Rp 1.538.000.000.000,00 dan Initial Capital Cost $\mathrm{Rp}$ 379.000.000.000,00 dan Cost of Energy (COE) Rp 823,64. Hasil simulasi renewable fraction, Homer mendapatkan nilai $75,0 \%$.

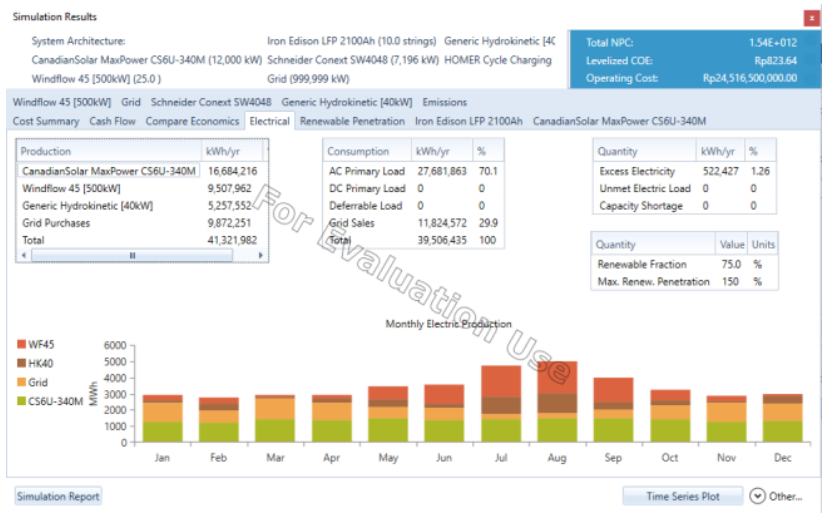

Gbr 8. Hasil produksi listrik masing-masing komponen

Produksi energi pada sistem ini didominasi oleh PV, hal ini dapat dilihat dari warna hijau yang mendominasi setiap bulannya secara keseluruhan sistem menghasilkan energi listrik sebesar $41.321 .982 \mathrm{kWh} / \mathrm{yr}$, sedangkan total keseluruhan konsumsi beban ditambah penjualan listrik sebesar $39.506 .435 \mathrm{kWh} / \mathrm{yr}$. 


\section{Hasil Analisis}

Pada analisis sensistifitas ini faktor yang paling berpengaruh adalah nilai perubahan ekonomi berdasarkan angka kenaikan inflasi. Nilai masingmasing kategori dilakukan analisa sensitifitas untuk mengantisipasi kemungkinan terjadinya perubahan nilai inflasi pada beberapa tahun kedepan, dari setiap perubahan akan menentukan konfigurasi dari sistem. Sistem pembangkit energi hybrid on grid Pesisir Pantai Pangandaran akan dilakukan 2 nilai kategori analisis sensitifitas yaitu analisis sensitifitas kenaikan persentasi inflasi dan penurunan persensatasi inflasi sebesar 5\% dan $3 \%$.

Tbl 5. Perbandingan kondisi-kondisi sensitifitas kecepatan angin dan gelombang terhadap radiasi matahari optimasi analisis sensitifitas

\begin{tabular}{lccc}
\hline Kondisi & Sensitifitas & $\begin{array}{c}\text { NPC } \\
(\mathbf{R p})\end{array}$ & COE (Rp) \\
\hline 1 & Kenaikan nilai & $\mathrm{Rp}$ & $\mathrm{Rp} \mathrm{763,72}$ \\
& faktor ekonomi & 1,755 & \\
& dengan nilai & Triliun & \\
& inflasi 5\% & & \\
\hline 2 & Kenaikan nilai & $\mathrm{Rp}$ & $\mathrm{Rp} \mathrm{896,62}$ \\
& faktor ekonomi & 1,33 & \\
& dengan nilai & Triliun & \\
& inflasi 3\% & & \\
& & &
\end{tabular}

Faktor Emisi

Pada sistem pembangkit tenaga hybrid on grid di Pesisir Pantai Pangandaran ini ketika konfigurasi sistem optimal menghasilkan emisi karbon dioksida sebesar 6.239.263 kg/yr, 0 carbon monoksida, $27.050 \mathrm{~kg} / \mathrm{yr}$ sulfur dioksida dan 13.229 nitrogen oksida ditunjukan pada gambar 9.

\begin{tabular}{|l|l|l|}
\hline Quantity & Value & Units \\
\hline Carbon Dioxide & $6,239,263$ & $\mathrm{~kg} / \mathrm{yr}$ \\
Carbon Monoxide & 0 & $\mathrm{~kg} / \mathrm{yr}$ \\
Unburned Hydrocarbons & 0 & $\mathrm{~kg} / \mathrm{yr}$ \\
Particulate Matter & 0 & $\mathrm{~kg} / \mathrm{yr}$ \\
Sullour Dioxide & 27,050 & $\mathrm{~kg} / \mathrm{yr}$ \\
Nitrogeb Oxides/7 & 13,229 & $\mathrm{~kg} / \mathrm{yr}$ \\
\hline
\end{tabular}

Gbr 9. Emisi

Analisis Nilai Ekonomis pada Sistem Pembangkit

A. Kondisi 1 (hanya terhubung jaringan PLN)

Tbl 6. Nilai ekonomi dari grid PLN pada kondisi 1

\begin{tabular}{ll}
\hline \multicolumn{1}{c}{ Parameter } & \multicolumn{1}{c}{ Nilai } \\
\hline Total produksi energi & 27.681 .826 \\
(kWh/tahun) & $\mathrm{kWh} / \mathrm{tahun}$ \\
\hline Konsumsi energi & 27.681 .826 \\
(kWh/tahun) & $\mathrm{kWh} / \mathrm{tahun}$ \\
\hline Net Present Cost $(\mathrm{Rp})$ & $\mathrm{Rp}$ \\
& $1.931 .000 .000 .000,00$ \\
\hline Cost of Energy & $\mathrm{Rp} \mathrm{1476,00}$ \\
\hline Renewable Penetration $(\%)$ & $0 \%$ \\
\hline
\end{tabular}

\begin{tabular}{ll}
\hline Annualized cost & $\mathrm{Rp}$ \\
& $40.858 .429 .492,80$ \\
\hline
\end{tabular}

Nilai konsumsi energi merupakan pemakaian energi yang berasal dari beban elektronik yang dipakai sebesar 27.681.826kWh/tahun. Dari hasil optimasi yang terhubung jaringan PLN dengan Net Present Cost memiliki nilai sebesar Rp 1.931.000.000.000,00 Cost of Energy sebesar Rp 1476,00.

$\mathrm{COE}=\frac{40.858 .429 .492,80}{27.681 .826}$

$\mathrm{COE}=\mathrm{Rp} 1476,00$

B. Kondisi 2 (sistem tenaga hybrid on grid energi terbarukan )

Tb1 7. Nilai ekonomis sistem tenaga hybrid on grid energi terbarukan

\begin{tabular}{ll}
\hline \multicolumn{1}{c}{ Parameter } & \multicolumn{1}{c}{ Nilai } \\
\hline $\begin{array}{l}\text { Total produksi tahunan } \\
\text { (kWh/tahun) }\end{array}$ & $41.321 .982 \mathrm{kWh} /$ tahun \\
\hline Konsumsi Energi & $39.506 .435 \mathrm{kWh} / \mathrm{tahun}$ \\
\hline Net Present Cost $(\mathrm{Rp})$ & $\mathrm{Rp} 1.538 .000 .000 .000,00$ \\
\hline Cost of Energy & $\mathrm{Rp} 823,64$ \\
\hline $\begin{array}{l}\text { Renewable Penetration } \\
(\%)\end{array}$ & $75,0 \%$ \\
\hline Annualized cost & $\mathrm{Rp} 32.539 .070 .747,09$ \\
\hline
\end{tabular}

Nilai konsumsi energi merupakan pemakaian energi yang berasal dari beban elektronik yang dipakai sebesar 39.506.435 kWh/tahun. Dari hasil optimasi yang terhubung jaringan PLN dengan Net Present Cost memiliki nilai sebesar Rp Rp 1.538.000.000.000,00.

$\mathrm{COE}=\frac{32.539 \cdot 070.747,09}{39.506 .435}$
$\mathrm{COE}=\operatorname{Rp} 823,64$

Perbandingan Nilai Ekonomis

Tbl 8. Perbandingan kondisi 1 (jaringan PLN), dan kondisi 2 (sistem tenaga hybrid on grid energi terbarukan)

\begin{tabular}{lcc}
\hline \multirow{1}{*}{ Parameter } & \multicolumn{2}{c}{ Sistem Pembangkit } \\
\cline { 2 - 3 } & Kondisi 1 & Kondisi 2 \\
\hline Total produksi & 27.681 .826 & 41.321 .982 \\
(kWh) & $\mathrm{kWh} / \mathrm{tahun}$ & $\mathrm{kWh} / \mathrm{tahun}$ \\
\hline Produksi grid & 27.681 .826 & 9.872 .251 \\
(kWh) & $\mathrm{kWh} / \mathrm{tahun}$ & $\mathrm{kWh} / \mathrm{tahun}$ \\
\hline Produksi & 0 & 31.449 .731 \\
renewable & & $\mathrm{kWh} / \mathrm{tahun}$ \\
energy $(\mathrm{kWh})$ & & \\
\hline Komsumsi & 27.681 .826 & 39.506 .435 \\
energi & $\mathrm{kWh} / \mathrm{tahun}$ & $\mathrm{kWh} / \mathrm{tahun}$ \\
(kWh/tahun) & & \\
\hline $\begin{array}{l}\text { Grid sales } \\
\text { (kWh) }\end{array}$ & 0 & $11.824 .572 \mathrm{kWh}$ \\
\hline Net present cost & & \\
(Rp) & $\mathrm{Rp}$ & $\mathrm{Rp}$ \\
& 1.931 .000 .000 .0 & 1.538 .000 .000 .0 \\
\hline Cost of Energy & $\mathrm{Rp} \mathrm{1.476,00}$ & $\mathrm{Rp} 823,64$ \\
\hline
\end{tabular}




\begin{tabular}{lcc}
\hline (Rp/kWh) & \\
\hline $\begin{array}{l}\text { Renewable } \\
\text { fraction }\end{array}$ & $0 \%$ & $75,0 \%$ \\
\hline
\end{tabular}

Berdasarkan tabel 8 perbandingan nilai ekonomis pada kondisi 1 dan kondisi 2 pada proyeksi jangka panjang nilai-nilai pada kondisi 2 lebih murah dan ekonomis. Kelayakan perencanaan kondisi 2 dapat dilihat dari produksi energi, nilai NPC dan COE yang lebih menguntungkan.

Konfigurasi yang baik adalah konfigurasi dengan net present cost paling rendah. Net present cost merupakan nilai saat ini dari semua biaya yang muncul selama masa pakai dikurangi semua pendapatan yang diperoleh selama masa pakai sedangkan cost of energy merupakan biaya rata-rata per $\mathrm{kWh}$ dari energi listrik yang tergantung yang dihasilkan oleh sistem pembangkit.
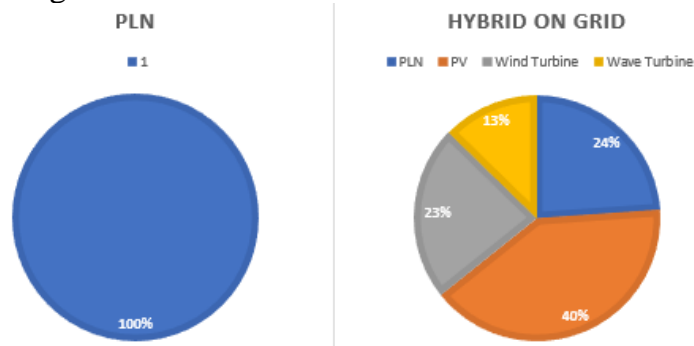

Gbr 10. Grafik persentase produksi energi kondisi 1 dan kondisi 2

Perbandingan grafik persentasi produksi listrik pada gambar 4.9 yaitu pada kondisi satu (jaringan PLN) listrik $100 \%$ disuplai oleh PLN dengan jumlah produksi listrik 27,6 gW/tahun, sedangkan pada kondisi 2 (hybrid on grid) yaitu terdiri dari $24 \%$ PLN, $40 \%$ PV, $23 \%$ turbin angin dan $13 \%$ turbin ombak laut dengan jumlah produksi listrik mencapai 41,3 $\mathrm{gW} / \mathrm{th}$.

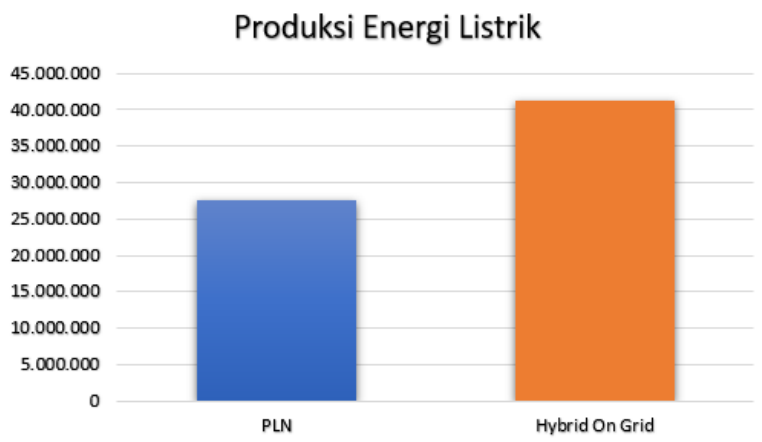

Gbr 11. Grafik perbandingan produksi energi listrik

Grafik persentasi produksi listrik menunjukan bahwa produksi listrik untuk pembangkit listrik tenaga hybrid on grid dengan jumlah produksi listrik lebih besar dari beban listrik Kecamatan Pangandaran, kelebihan energi pada kondisi 2 (hybrid on grid) dapat dijual pada PLN dan disimpan pada battery bank.

\begin{tabular}{|c|c|c|c|c|c|}
\hline \multicolumn{3}{|c|}{ SISTEM JARINGAN PLN } & \multicolumn{3}{|c|}{ SISTEM PEMBANGKIT HYBRID ON GRID } \\
\hline Quantity & Value & Units & Quantity & Value & Units \\
\hline Carbon Dioxide & $17,494,937$ & $\mathrm{~kg} / \mathrm{yr}$ & Carbon Dioxide & $6,239,263$ & $\mathrm{~kg} / \mathrm{yr}$ \\
\hline Carbon Monoxide & 0 & $\mathrm{~kg} / \mathrm{yr}$ & Carbon Monoxide & 0 & $\mathrm{~kg} / \mathrm{yr}$ \\
\hline Unburned Hydrocarbons & 0 & $\mathrm{~kg} / \mathrm{yr}$ & Unburned Hydrocarbons & 0 & $\mathrm{~kg} / \mathrm{yr}$ \\
\hline Particulate Matter & 0 & $\mathrm{~kg} / \mathrm{yr}$ & Particulate Matter & 0 & $\mathrm{~kg} / \mathrm{yr}$ \\
\hline Sulfur Dioxide & 75,848 & $\mathrm{~kg} / \mathrm{yr}$ & Sulfur Dioxide & 27,050 & $\mathrm{~kg} / \mathrm{yr}$ \\
\hline Nitrogen Oxides & 37,094 & $\mathrm{~kg} / \mathrm{yr}$ & Nitrogen Oxides/? & 13,229 & $\mathrm{~kg} / \mathrm{yr}$ \\
\hline
\end{tabular}

Gbr 12. Perbandingan emisi sistem jaringan PLN dan sistem pembangkit Hybrid on grid

Pada sistem jaringan PLN di Pesisir Pantai Pangandaran ini ketika konfigurasi sistem optimal menghasilkan emisi karbon dioksida sebesar 17.495.937 kg/tahun, 0 karbon monoksida, $75.848 \mathrm{~kg} /$ tahun sulfur dioksida dan $37.094 \mathrm{~kg} / \mathrm{tahun}$ nitrogen dioksida. Sedangkan sistem pembangkit hybrid on grid ketika konfigurasi sistem optimal hanya menghasilkan emisi karbon dioksida sebesar 6.239.263 kg/tahun, 0 carbon monoksida, $27.050 \mathrm{~kg} /$ tahun sulfur dioksida dan 13.229 $\mathrm{kg} /$ tahun nitrogen oksida.

\section{KESIMPULAN}

1. Pesisisr Pantai Pangandaran di Kecamatan Pangandaran memiliki potensi sumber daya matahari, angin dan gelombang air laut yang cukup besar dengan rata-rata radiasi matahari 4,6 $\mathrm{kWh} / \mathrm{m}^{2} / \mathrm{d}$, kecepatan angin 4,42 m/s, dan kecepatan gelombang air laut $30,49 \mathrm{~m} / \mathrm{s}$. Hasil simulasi HOMER didapatkan nilai radiasi matahari terendah pada bulan januari sebesar $4,35 \mathrm{kWh} / \mathrm{m}^{2} / \mathrm{d}$, radiasi matahari tertinggi pada bulan agustus mencapai 5,03 , kecepatan angin terendah pada bulan november sebesar $3,04 \mathrm{~m} / \mathrm{s}$ kecepatan angin tertinggi pada bulan juni mencapai $5,9 \mathrm{~m} / \mathrm{s}$ dan kecepatan gelombang air laut terendah ada pada bulan januari, maret serta november sebesar 25,7 $\mathrm{m} / \mathrm{s}$, kecepatan gelombang tertinggi pada bulan agustus mencapai $36,35 \mathrm{~m} / \mathrm{dt}$.

2. Net present cost (NPC) mencakup biaya keseluruhan sistem selama jangka waktu tertentu, konfigurasi yang optimal ditentukan oleh besaran net present cost (NPC) yang terendah. Hasil simulasi HOMER mendapatkan konfigurasi sistem yang optimal dari net present cost terendah berupa sistem yang terhubung jaringan PLN dan komponen energi terbarukan berupa $0,34 \mathrm{~kW}$ panel surya, $500 \mathrm{~kW}$ turbin angin, $2100 \mathrm{Ah} 48 \mathrm{~V}$ baterai, $40 \mathrm{~kW}$ turbin gelombang laut dan konverter $3 \mathrm{~kW}$ dengan net present cost sebesar Rp 1,538 triliun, initial capital cost Rp 379 miliar dan cost of energy $\mathrm{Rp}$ $823,64 / \mathrm{kWh}$. Mendapatkan nilai renewable fraction mencapai $75,0 \%$. Sedangkan konfigurasi sistem dengan net present cost (NPC) tertinggi berupa sistem yang terhubung jaringan PLN dan komponen energi terbarukan berupa $0,34 \mathrm{~kW}$ panel surya, 500 $\mathrm{kW}$ turbin angin, $40 \mathrm{~kW}$ turbin gelombang laut dan konverter $3 \mathrm{~kW}$ dengan net present cost sebesar Rp 1,551 triliun, initial capital cost Rp 372 miliar dan cost of energy $\mathrm{Rp} 830,81 / \mathrm{kWh}$. Mendapatkan nilai renewable fraction mencapai $75,0 \%$. 
3. Berdasarkan hasil yang diperoleh dengan simulasi menggunakan HOMER, perencanaan sistem pembangkit listrik hybrid on grid di Pesisir Pantai Kecamatan Pangandaran memliki potensi energi yang dapat digunakan sebagai sumber energi listrik yang berasal dari panel surya, turbin angin dan turbin gelombang air laut terhubung jaringan PLN dengan total produksi 41.321.982 $\mathrm{kWh} /$ tahun dan jika dibandingkan sistem pembangkit jaringan PLN dengan total produksi 27.681.826 $\mathrm{kWh} /$ tahun sistem hybrid on grid memiliki kelebihan yaitu mendapatkan net present cost lebih rendah yaitu 1,5 triliun sedangkan pada jaringan PLN mencapai 1,9 triliun dalam jangka waktu 25 tahun, kelebihan energi dapat dijual kembali ke PLN.

\section{DAFTAR PUSTAKA}

[1] DINAS KOMINFO, "Informasi Pangandaran," 2019, 2013. [Online]. Available:

http://pangandarankab.go.id/.

[2] Y.Daryanto, "Kajian Potensi angin Untuk

Pembangkit Listrik Tenaga Bayu," Blueprint, no. April, 2007.

[3] O. A. Rosyid, B. Besar, T. Energi, and K. P. Serpong, "Pembangkit listrik tenaga surya hibrida untuk listrik pedesaan di indonesia," vol. 01, no. 01, pp. 3138,2011 .

[4] H. H. Pradana and H. Mubarok, "Simulasi Sistem Pembangkit Listrik Hibrid Tenaga Surya Dan Angin Di Fakultas Teknologi Industri," Kurvatek, vol. 3, no. 2, p. 101, 2019.

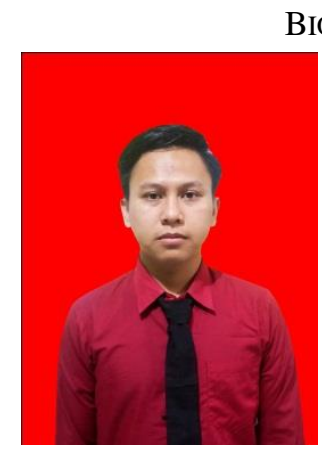

\section{BIOGRAFI PENULIS}

Abil W Akbar, lahir di daerah pedesaan tepatnya di Banjarwaru Priangan Timur 19 November tahun 1995, menempuh pendidikan S1 Teknik Elektro di Universitas Siliwangi Tasikmalaya tahun 2015 sampai dengan 2019, dan konsentrasi penelitian pada bidang Energi Baru Terbarukan (EBT) hybrid pada tahun 2018. Kesibukannya saat ini yaitu menjadi anggota team dalam projek pengembangan teknologi persinyalan perkeretaapian Indoneisa di PT.LEN INDUSTRI Bandung Jawa Barat. 